Prepared in cooperation with the U.S. Fish and Wildlife Service and East Bay Regional Park District

\title{
Golden Eagle Population Surveys in the Vicinity of the Altamont Pass Wind Resource Area, California, 2014-21
}

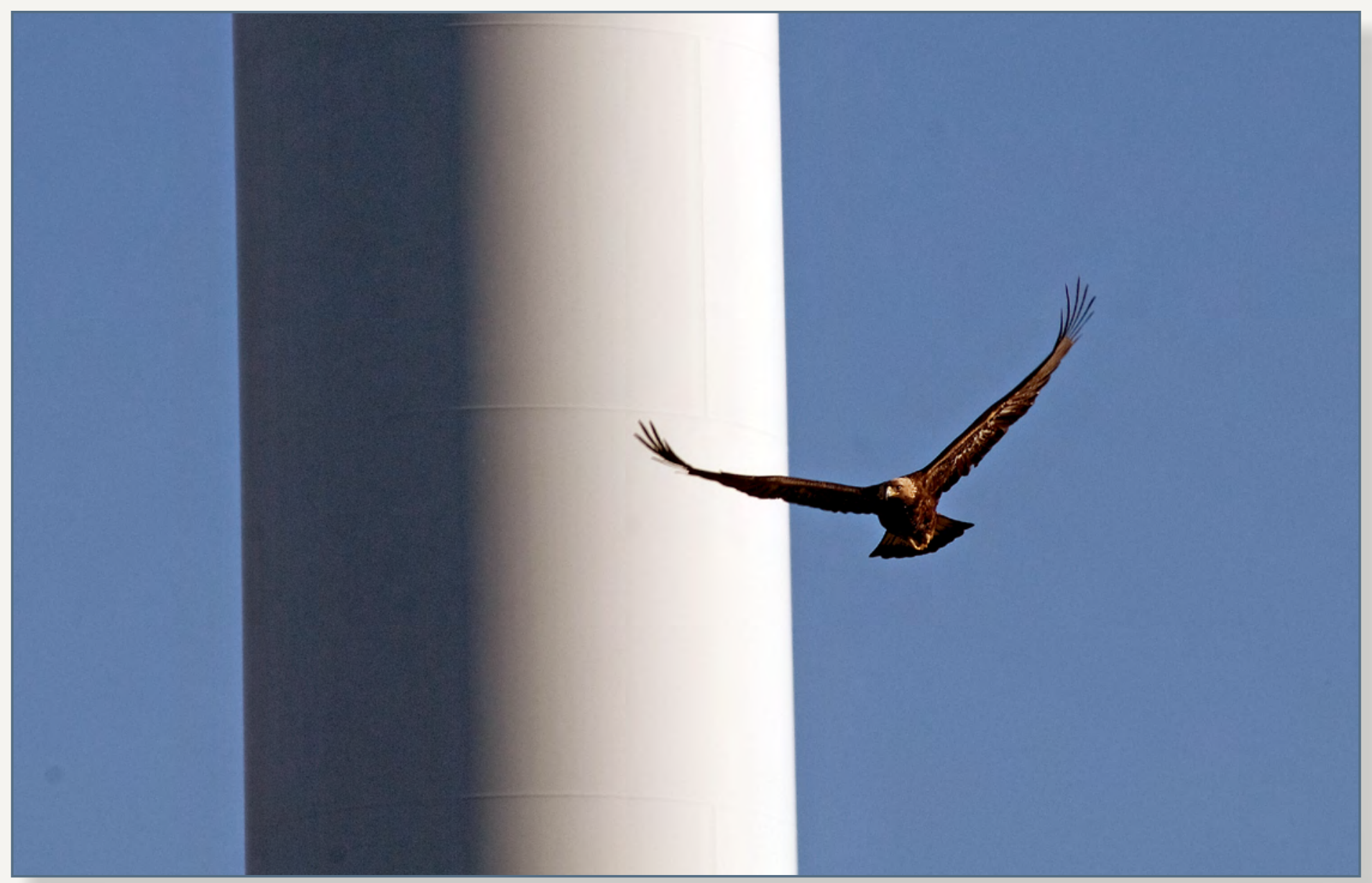

Open-File Report 2021-1107 
Cover: Golden Eagle soaring near a wind turbine tower in the Altamont Pass Wind Resource Area, California, 2021. Photo by Patrick Kolar, U.S. Geological Survey. 


\section{Golden Eagle Population Surveys in the Vicinity of the Altamont Pass Wind Resource Area, California, 2014-21}

By J. David Wiens and Patrick S. Kolar

Prepared in cooperation with the U.S. Fish and Wildlife Service and East Bay

Regional Park District

Open-File Report 2021-1107 


\section{U.S. Geological Survey, Reston, Virginia: 2021}

For more information on the USGS - the Federal source for science about the Earth, its natural and living resources, natural hazards, and the environment—visit https://www.usgs.gov or call 1-888-ASK-USGS.

For an overview of USGS information products, including maps, imagery, and publications, visit https://store.usgs.gov/.

Any use of trade, firm, or product names is for descriptive purposes only and does not imply endorsement by the U.S. Government.

Although this information product, for the most part, is in the public domain, it also may contain copyrighted materials as noted in the text. Permission to reproduce copyrighted items must be secured from the copyright owner.

The findings and conclusions in this report are those of the authors and do not necessarily represent the views of the U.S. Fish and Wildlife Service.

Suggested citation:

Wiens, J.D., and Kolar, P.S., 2021, Golden eagle population surveys in the vicinity of the Altamont Pass Wind Resource Area, California, 2014-21: U.S. Geological Survey Open-File Report 2021-1107, 18 p., https://doi.org/ 10.3133/ofr20211107.

ISSN 2331-1258 (online) 


\section{Contents}

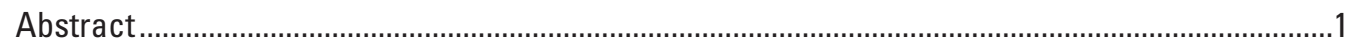

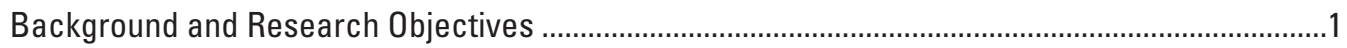

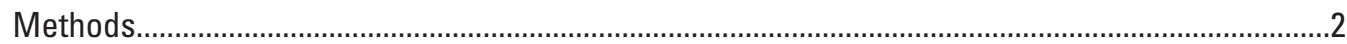

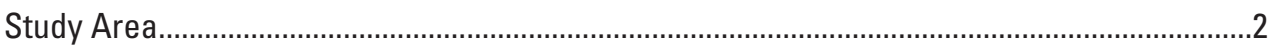

Golden Eagle Monitoring Design and Survey Protocol ...........................................................2

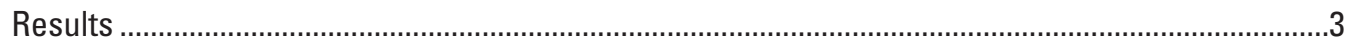

Site Occupancy and Reproduction .......................................................................................

Northern Diablo Range and Altamont Wind Resource Area..............................................3

Altamont Pass Wind Resource Area ..........................................................................

Observations of Territorial and Non-territorial Subadults ..........................................................

Communal Roosting Behavior ...................................................................................................

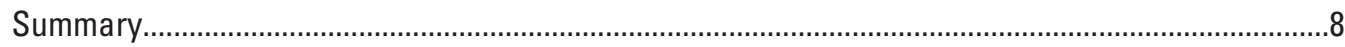

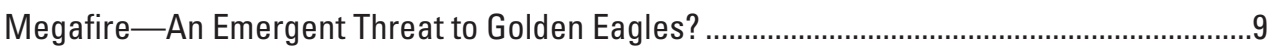

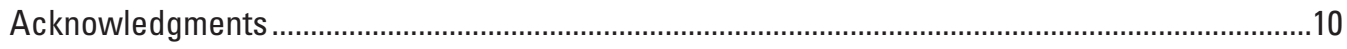

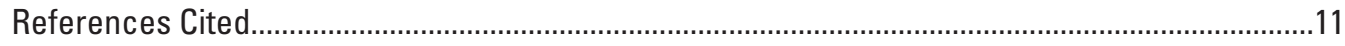

Appendix 1. Map of Survey Sites and Activity Centers Used by Territorial Pairs of Golden Eagles in the Altamont Pass Wind Resource Area, 2019-21 ................................13

Appendix 2. Territory-Specific Observations of Territorial Pairs of Golden Eagles Located near the Altamont Pass Wind Resource Area, 2019-21.......................................14

\section{Figures}

1. Map showing the northern Diablo Range study area, showing the distribution of randomly selected survey sites that were repeatedly searched for evidence of occupancy and reproduction by Golden Eagles during 2014-21......................................

2. Graph showing territorial pairs of Golden Eagles associated with the APWRA consistently included a higher proportion of subadult pair members relative to the surrounding Diablo Range study area during 2014-21 ..............................................

3. Spatial distribution of detections of non-territorial Golden Eagles with subadult plumage in the northern Diablo Range study area, 2014-21

4. Map showing the location of the 2020 Santa Clara Unit Lightning Complex Fire in relation to the distribution of sites surveyed for Golden Eagles annually during 2014-21

\section{Tables}

1. Survey effort and detections of territorial pairs of Golden Eagles in the northern Diablo Range and Altamont Pass Wind Resource Area, California, 2014-21

2. Measures of annual reproduction for territorial pairs of Golden Eagles monitored in the northern Diablo Range and Altamont Pass Wind Resource Area, California, 2014-21. 


\section{Conversion Factors}

International System of Units to U.S. customary units

\begin{tabular}{lll}
\hline \multicolumn{1}{c}{ Multiply } & By & \multicolumn{1}{c}{ To obtain } \\
\hline & Length & foot (ft) \\
meter $(\mathrm{m})$ & 3.281 & mile (mi) \\
kilometer $(\mathrm{km})$ & 0.6214 & \\
\hline & Area & acre \\
hectare (ha) & 2.471 & square mile $\left(\mathrm{mi}^{2}\right)$ \\
square kilometer $\left(\mathrm{km}^{2}\right)$ & 0.3861 & \\
\hline
\end{tabular}

\section{Datum}

Vertical coordinate information is referenced to the North American Vertical Datum of 1988 (NAVD 88).

Horizontal coordinate information is referenced to the North American Datum of 1983 (NAD 83). Altitude, as used in this report, refers to distance above the vertical datum. 


\title{
Golden Eagle Population Surveys in the Vicinity of the Altamont Pass Wind Resource Area, California, 2014-21
}

\author{
By J. David Wiens and Patrick S. Kolar
}

\section{Abstract}

Golden Eagles (Aquila chrysaetos) are among the highest profile species killed by collisions with wind turbines at the Altamont Pass Wind Resource Area (APWRA) in the northern Diablo Range of west-central California. Understanding the distribution, site occupancy, and nesting status of eagles near the APWRA is needed to identify and minimize possible population-level impacts. We established a broad-scale survey design across a 5,185-km square-kilometer region of the Diablo Range, including the APWRA, to monitor site occupancy, abundance, and reproduction of Golden Eagles. During the study period we identified as many as 230 territorial pairs of Golden Eagles in the study area, up to 21 of which overlapped with the APWRA in any given year. On average, we detected a similar density of pairs at sites surveyed in the APWRA (1 pair per $17.8 \mathrm{~km}^{2}$ surveyed) relative to sites surveyed in the surrounding region (1 pair per $20.3 \mathrm{~km}^{2}$ surveyed). In 2020 and 2021, estimates of the proportion of pairs that successfully fledged at least one young (nesting success) were 0.27 and 0.26 , respectively, which were above the sevenyear average (0.22). On average, eagle pairs monitored in the APWRA had similar reproductive output $(0.37$ young fledged per pair) relative to pairs monitored outside of the APWRA ( 0.30 young fledged per pair). We observed a substantially higher proportion of territorial subadult pair members at the APWRA (mean $=29$ percent of 16 pairs aged) relative to pairs monitored and aged in the surrounding region $($ mean $=$ 3 percent of 122 pairs), indicating potentially higher rates of adult mortality or displacement at territories overlapping with the APWRA. Emergent threats to eagles in the study region, including a severe wildfire that impacted over 60 historical breeding territories in 2020, may interact with existing threats to affect population status and thus warrants further investigation. Our study provides wind energy developers, land managers, and regulatory agencies with key information on the spatial distribution, habitat quality, and population status of Golden Eagles needed to promote compatible wind energy production and long-term conservation of this federally protected wildlife species.

\section{Background and Research Objectives}

Golden Eagles (Aquila chrysaetos) are an increasing global conservation concern and are among the highest profile wildlife species killed by collisions with wind turbines at the Altamont Pass Wind Resource Area (APWRA; Orloff and Flannery, 1992; Smallwood and Thelander, 2008; Hunt and others, 2017). A clear understanding of the distribution, nesting activity, and population status of Golden Eagles exposed to increased mortality risk at wind-energy facilities is needed for conservation planning and permitting purposes (U.S. Fish and Wildlife Service, 2013). To address these needs, we established a broad-scale study to estimate site occupancy, reproduction, abundance, and habitat quality of Golden Eagles in the northern Diablo Range and APWRA (Wiens and others, 2015, 2018, 2020; Kolar and Wiens, 2017). The probabilistic sampling design used in this study provides statistically robust information on the distribution and annual reproductive status of territorial pairs of eagles, in addition to site-use by nonterritorial subadults (birds 1-4 years old), across landscapes with and without wind turbines. This information enables a more comprehensive understanding of the population-level impacts of multiple interacting stressors, including wind energy production, to Golden Eagles and their habitats.

Targeted monitoring of Golden Eagle populations is an integral component of effective management, serving as a guide for deciding the appropriate course of management action, evaluating the effectiveness of such actions, and providing options to better achieve management goals. At the APWRA, monitoring of the local population of Golden Eagles has provided a strong foundation for evaluating future changes in the population and determining how wind-energy related mortality may interact with other, emerging threats such as severe drought and large wildfires to affect management and conservation of this federally protected species. This report summarizes population surveys of Golden Eagles completed in the northern Diablo Range and the APWRA during 2014-21 (surveys were not completed in 2017). Specifically, we summarize: (1) site occupancy, reproduction, and numbers of territorial pairs of Golden Eagles detected annually; and (2) annual observations of subadult Golden Eagles (including territorial pair members and non-territorial individuals). We further document annual observations of territorial pairs of Golden 
Eagles, including nesting and roosting locations, within 3.2 $\mathrm{km}$ of the APWRA. We focus primarily on more recent findings from 2019 to 2021; results from population surveys completed in 2014-18 are provided elsewhere (Wiens and others, 2015, 2018, 2020; Kolar and Wiens, 2017). This information should be considered preliminary, serving as baseline information for forthcoming analyses.

\section{Methods}

\section{Study Area}

The 5,185-square kilometer $\left(\mathrm{km}^{2}\right)$ study area was in the northern Diablo Range of west-central California and included the APWRA (fig. 1). Current management guidelines for Golden Eagles consider occupied territories overlapping a 2-mile (3.2 kilometer $[\mathrm{km}]$ ) radius with wind-energy project boundaries to be at risk of disturbance, injury, or death resulting from activities associated with operations of the development and infrastructure (U.S. Fish and Wildlife Service, 2013). Therefore, we considered a 3.2-km radius (total area $=363 \mathrm{~km}^{2}$ ) around locations of historical and existing wind turbines to distinguish survey efforts and eagles located near the APWRA, from those in the broader northern Diablo Range (fig. 1). This study area included private ranchlands with livestock grazing, in addition to state, county, and municipal lands that received variable amounts of grazing and recreational use. Nesting substrates used by Golden Eagles in the Diablo Range study area were predominantly oak (Quercus spp.), conifer (Pinus spp.), California Bay Laurel (Umbellularia californica), Western Sycamore (Platanus racemose), cottonwood (Populus spp.), non-native tree species such as eucalyptus (Eucalyptus spp.), 230 kilovolt transmission line towers, and rarely, small cliff faces and rock outcrops (Kolar and Wiens, 2017).

\section{Golden Eagle Monitoring Design and Survey Protocol}

We combined a standard site-occupancy study design (MacKenzie and others, 2017) with general recommendations of Driscoll (2010) and Pagel and others (2010) to survey and monitor the focal population of Golden Eagles. We conducted repeated (2-4) surveys at a sample of 152 survey sites we randomly selected from a grid of 373 equally sized $\left(13.9 \mathrm{~km}^{2}\right)$ hexagon cells overlaid on the study area (fig. 1). We considered each hexagon cell as a 'site' where observers conducted repeated area searches for evidence of occupancy, use, and reproduction by Golden Eagles. During surveys observers recorded the location, number, age, and behaviors of all Golden Eagles detected. We mapped all perches, flight paths, territorial displays, and locations of nests and fledged young to approximate annual activity centers used by territorial pairs. When possible, we also monitored pairs of eagles regularly detected in hexagons adjacent to our focal (randomly selected) hexagons, which allowed us to better distinguish among territorial pairs with activity centers in focal versus non-focal survey sites. We surveyed sites with pair detections in mid-June to late-July to locate nests or fledglings where reproduction was not previously confirmed and to determine the number of young fledged per territorial pair. We attempted to classify all Golden Eagles detected in focal and non-focal survey sites as subadults (1-4 years old) or adults based on visible plumage characteristics (see Kolar and Wiens, 2017). Additional details on the study area, sampling design, aging methods, and field protocols we used are provided elsewhere (Wiens and others, 2015, 2018; Kolar and Wiens, 2017). Because detection probabilities of Golden Eagles are below 1 (Wiens and others, 2018, 2020), empirical data reported here may underestimate site occupancy, reproduction, and numbers of Golden Eagles present. 


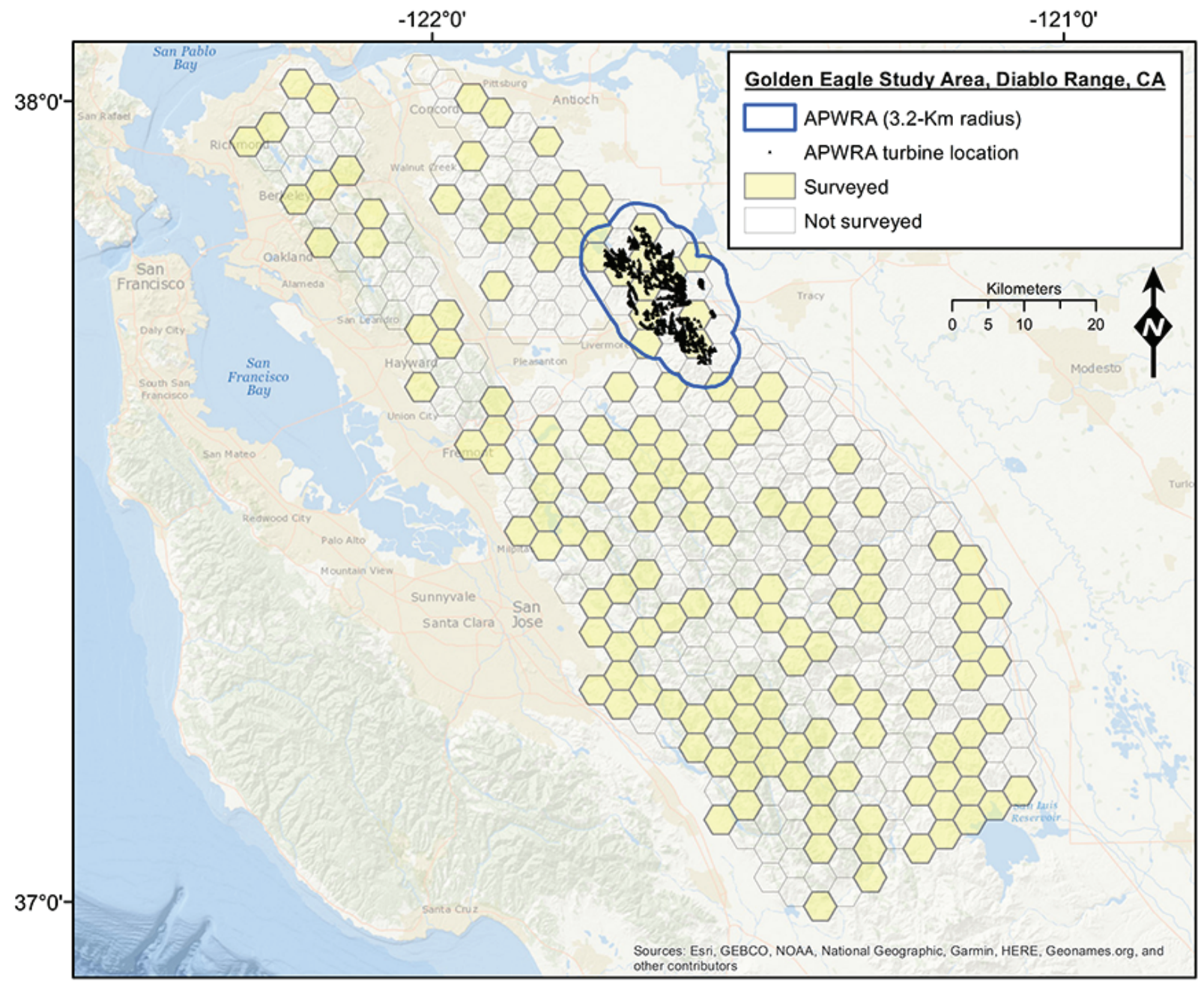

Figure 1. Northern Diablo Range study area, showing the distribution of randomly selected survey sites (13.9 square kilometer hexagons) that were repeatedly searched for evidence of occupancy and reproduction by Golden Eagles during 2014-21 (surveys were not completed in 2017). The Altamont Pass Wind Resource Area (APWRA) was delineated by a $3.2 \mathrm{~km}$ (2-mile) radius around historical and current (operational) wind turbine locations.

\section{Results}

\section{Site Occupancy and Reproduction}

\section{Northern Diablo Range and Altamont Wind Resource Area}

From 2014 to 2021 (no surveys were completed in 2017), we conducted 2,946 surveys at as many as 152 randomly selected (focal) sites in the northern Diablo Range study area and APWRA combined (table 1) 1 . The proportion of sites with detections of at least 1 pair of Golden Eagles (naïve occupancy) ranged from a low of 0.55 in 2020 to a high of 0.66 in

\footnotetext{
${ }^{1}$ Does not include 13 additional sites in the East Contra Costa Habitat Conservation Plan Inventory Area that were surveyed in 2019; for details see Wiens and others (2020).
}

2014-15. Surveys in 2019 and 2020 were more limited relative to previous years because of budget limitations, weatherrelated road closures, and changes in land-access to some survey sites. During the 2021 season, we reestablished surveys at many of the sites covered in previous years. In both 2019 and 2020, we detected at least one territorial pair of Golden Eagles at 65 focal survey sites, representing 58 percent of sites surveyed in 2019 and 55 percent of sites surveyed in 2020 .

During 2021, we detected at least one territorial pair of Golden Eagles at 79 sites, representing 60 percent of sites surveyed. In 2019 , we detected 71 total pairs at 113 sites surveyed (mean $=0.63$ pairs detected per site), in 2020 we detected 74 pairs at 118 sites surveyed (mean $=0.63$ pairs detected per site), and in 2021 we detected 90 pairs at 132 sites surveyed (mean $=0.68$ pairs detected per site; table 1). These estimates do not include repeated detections of single territorial adult Golden Eagles at two different survey sites in 2019 and 2021. 
Table 1. Survey effort and detections of territorial pairs of Golden Eagles in the northern Diablo Range and Altamont Pass Wind Resource Area (APWRA), California, 2014-21 (surveys were not completed in 2017).

[Survey sites were defined as $13.9 \mathrm{~km}^{2}$ hexagons. The APWRA was delineated by a 3.2-km buffer radius around historical and current wind turbine locations. Estimates do not include observations of additional pairs of eagles occupying outside the boundary of focal, randomly selected survey sites].

\begin{tabular}{|c|c|c|c|c|c|c|c|c|}
\hline Area & 2014 & 2015 & 2016 & 2018 & 2019 & 2020 & 2021 & $\begin{array}{c}\text { Study } \\
\text { average }\end{array}$ \\
\hline \multicolumn{9}{|c|}{ Diablo Range and APWRA combined } \\
\hline Sites with at least 1 territorial pair detected & 88 & 89 & 89 & 84 & 65 & 65 & 79 & 80 \\
\hline Proportion of sites with pairs & 0.66 & 0.66 & 0.65 & 0.61 & 0.58 & 0.55 & 0.60 & 0.62 \\
\hline \multicolumn{9}{|c|}{ APWRA only } \\
\hline Sites surveyed & 13 & 13 & 13 & 13 & 12 & 13 & 13 & 13 \\
\hline Sites with at least 1 territorial pair detected & 9 & 10 & 10 & 10 & 9 & 8 & 9 & 9 \\
\hline Proportion of sites with pairs & 0.69 & 0.77 & 0.77 & 0.77 & 0.75 & 0.62 & 0.69 & 0.72 \\
\hline
\end{tabular}

During the study period the observed nesting rate (proportion of territorial pairs monitored with evidence of a nesting attempt) ranged from a low of 0.21 in 2014 to a high of 0.39 in 2020 . Observed nesting success (proportion of territorial pairs monitored that successfully fledged at least one young) during the same period ranged from a low of 0.15 in 2019 to a high of 0.30 in 2018 (table 2). We observed a moderate increase in reproductive measures in 2020 and 2021, especially for pairs monitored at the southern end of the study area. In 2019, we found evidence of nesting for 28 percent of 71 pairs monitored. Of the 20 pairs that nested, 9 (45 percent) failed to produce young, 8 (40 percent) fledged one young each, and 3 (15 percent) fledged two young each (mean number of young fledged per successful site $=1.27$; table 2 ). In 2020, we found evidence of nesting for 39 percent of 74 pairs monitored. Of the 29 pairs that nested, 9 (31 percent) failed to produce young, 13 (45 percent) fledged one young each, and 7 (24 percent) fledged two young each (mean number of young fledged per successful site $=1.35$ ). In 2021, we found evidence of nesting for 38 percent of 90 pairs monitored. Of the 34 pairs that nested, 11 (32 percent) failed to produce young, 13 (38 percent) fledged one young each, and 10 (29 percent) fledged two young each (mean number of young fledged per successful site $=1.43$ ).

When possible, we collected information on additional pairs of eagles with nests or activity centers outside the boundary of randomly selected 'focal' survey sites. Ancillary information on pairs detected in 'non-focal' sites (fig. 1) permitted us to better distinguish among different pairs of eagles, while also providing additional data on the distribution, abundance, and ages of pairs throughout the study region. In 2019, for example, we detected an additional 58 pairs of eagles in non-focal survey sites, in 2020 we detected an additional 70 pairs, and in 2021 we detected an additional 73 pairs. Thus, in focal and non-focal sites combined we detected a total of 129 , 144, and 163 territorial pairs of eagles in 2019, 2020, and 2021 respectively. When possible, we collected additional data on activity centers and nesting success of pairs in non-focal survey sites to validate statistical models in forthcoming analyses, provide more complete coverage of the APWRA (Kolar and Wiens, 2017), and to identify nesting locations for management activities associated with APWRA and elsewhere. In total we found 21 pairs nesting outside of focal areas in 2019, 15 of which fledged at least 19 young. In 2020 we found 30 pairs nesting outside of focal areas, 25 of which fledged at least 35 young. In 2021 we found 28 pairs nesting outside of focal areas, 21 of which fledged at least 29 young.

\section{Altamont Pass Wind Resource Area}

During the seven-year study period we conducted a total of 315 surveys at $12-13$ focal survey sites located within 3.2 $\mathrm{km}$ of the APWRA (fig. 1, table 1). The proportion of sites with detections of at least 1 pair of Golden Eagles (naïve occupancy) ranged from a low of 0.62 in 2020 to a high of 0.77 in 2015, 2016, and 2018. In 2019, we detected 10 pairs of eagles at 12 sites (mean $=0.83$ pairs detected per site), in 2020 we detected 9 pairs at 13 sites surveyed $($ mean $=0.69$ pairs detected per site; table 1), and in 2021 we detected 10 pairs of eagles at 13 sites (mean $=0.77$ pairs detected per site). One site located within the $3.2 \mathrm{~km}$ APWRA buffer was occupied by two pairs of eagles from 2019 to 2021 (app. 1, 2). We also monitored additional pairs of eagles occupying sites in the APWRA, 9 in 2019 and 2021, and 10 in 2020, with 
Table 2. Measures of annual reproduction for territorial pairs of Golden Eagles monitored in the northern Diablo Range and Altamont Pass Wind Resource Area (APWRA), California, 2014-21 (surveys were not completed in 2017).

[Survey sites were defined as $13.9 \mathrm{~km}^{2}$ hexagons. The APWRA was delineated by a 3.2-km buffer radius around historical and current wind turbine locations].

\begin{tabular}{|c|c|c|c|c|c|c|c|c|}
\hline Area & 2014 & 2015 & 2016 & 2018 & 2019 & 2020 & 2021 & $\begin{array}{c}\text { Study } \\
\text { average }\end{array}$ \\
\hline \multicolumn{9}{|c|}{ Diablo Range and APWRA combined } \\
\hline Number of pairs monitored & 96 & 99 & 98 & 91 & 71 & 74 & 90 & 88 \\
\hline Pairs with nesting attempt detected & 20 & ${ }^{3} 26$ & ${ }^{3} 28$ & 33 & 20 & 29 & 334 & 27 \\
\hline Pairs with successful nest detected & 17 & ${ }^{3} 16$ & 321 & 27 & 11 & 20 & 23 & 19 \\
\hline Observed nesting rate ${ }^{1}$ & 0.21 & 0.26 & 0.29 & 0.36 & 0.28 & 0.39 & 0.38 & 0.31 \\
\hline Observed nesting success ${ }^{2}$ & 0.18 & 0.16 & 0.21 & 0.30 & 0.15 & 0.27 & 0.26 & 0.22 \\
\hline Total fledged young detected & 22 & 20 & 30 & 40 & 14 & 27 & 33 & 27 \\
\hline Young fledged per pair monitored & 0.23 & 0.20 & 0.31 & 0.44 & 0.20 & 0.36 & 0.37 & 0.30 \\
\hline Young fledged per successful pair & 1.29 & 1.25 & 1.43 & 1.48 & 1.27 & 1.35 & 1.43 & 1.36 \\
\hline \multicolumn{9}{|c|}{ APWRA only } \\
\hline Number of pairs monitored & 9 & 11 & 10 & 11 & 10 & 9 & 10 & 10 \\
\hline Pairs with nesting attempt detected & 4 & 4 & 4 & 4 & 4 & 5 & 6 & 4 \\
\hline Pairs with successful nest detected & 3 & 0 & 2 & 2 & 2 & 4 & 3 & 2 \\
\hline Observed nesting rate ${ }^{1}$ & 0.44 & 0.36 & 0.40 & 0.36 & 0.40 & 0.56 & 0.60 & 0.45 \\
\hline Observed nesting success ${ }^{2}$ & 0.33 & 0.00 & 0.20 & 0.18 & 0.20 & 0.44 & 0.30 & 0.24 \\
\hline Total fledged young detected & 5 & 0 & 3 & 3 & 3 & 5 & 6 & 4 \\
\hline Young fledged per pair monitored & 0.56 & 0.00 & 0.30 & 0.27 & 0.30 & 0.56 & 0.60 & 0.37 \\
\hline Young fledged per successful pair & 1.67 & 0.00 & 1.50 & 1.50 & 1.50 & 1.25 & 2.00 & 1.35 \\
\hline
\end{tabular}

${ }^{1}$ Includes adults in incubation posture, nests with eggs/eggshells, or young present.

${ }^{2}$ At least one young fledged.

${ }^{3}$ Includes one site with two nesting pairs.

activity centers falling outside the boundary of focal survey sites. Thus, in total we identified 21 territorial pairs within the APWRA's 3.2-km boundary during the study period (fig. 1.1), although not all 21 pairs were detected and monitored within this area in each year (app. 2).

The observed nesting rate for territorial pairs detected in focal surveys sites within the APWRA's 3.2-km boundary ranged from 0.36 in 2015 and 2018 to 0.60 in 2021 (table 2). In 2019, four (40 percent) of the ten pairs monitored attempted to nest, but only two of these pairs successfully fledged a total of three young (mean number of young fledged per successful site $=1.50$ ). In 2020, five (56 percent) of nine pairs monitored attempted to nest, and 4 of these pairs successfully fledged a total of five young (mean number of young fledged per successful site $=1.25)$. In 2021, 6 (60 percent) of 10 pairs monitored attempted to nest, and 3 of these pairs successfully fledged a total of six young (mean number of young fledged per successful site $=2.00$ ).

When possible, we determined nesting status and productivity for territorial pairs of Golden Eagles detected outside of focal survey sites, but with activity centers located within 3.2 $\mathrm{km}$ of the APWRA. In 2019 we documented 9 additional pairs of eagles outside of focal survey sites, 5 of which nested and fledged a total of 4 young. In 2020 we detected 10 additional pairs of eagles, 6 of which nested and fledged a total of 9 young. In 2021 we found 9 additional pairs, 3 of which nested and fledged a total of 4 young. Detailed observations of all territorial pairs and their nesting activities at the APWRA are provided in appendixes 1 and 2.

\section{Observations of Territorial and Non-territorial Subadults}

During 2014-21 we were able to determine age class (subadult, adult) of territorial pair members at between 120 (2019) and 153 (2021) occupied territories annually in the Diablo Range and APWRA combined. We found that the incidence of subadult pair members was consistently greater for pairs with territories overlapping with the APWRA relative to pairs monitored in the surrounding landscapes of the northern Diablo Range (fig. 2). In 2021, five (28 percent) of 18 pairs monitored and aged within the APWRA were mixed-age pairs (that is, at least one member of the pair was in subadult plumage). In contrast, only two (two percent) of 128 pairs monitored and aged outside of the APWRA were mixed-age 
pairs. The relatively high proportion of subadult pair members at territories associated at the APWRA was consistent across all years of our study (fig. 2). On average, 29 percent of pairs monitored at the APWRA during 2014-21 included at least one subadult pair member, whereas only 3 percent of pairs monitored outside the APWRA included subadults. These observations suggested that territorial pairs located in or near the APWRA were 9-10 times more likely to consist of at least one subadult pair member relative to pairs occupying territories outside of the APWRA, on average.

Territorial subadults were observed engaging in territorial displays, constructing and refurbishing nests, and copulating with adult mates on numerous occasions, but we observed few cases of nesting by mixed-age pairs. During the seven-year study we documented only two nesting attempts by mixedage pairs within the APWRA: one of the six mixed-age pairs monitored in 2019 successfully fledged one young, and one of the four mixed-age pairs monitored in 2020 attempted to nest but was unsuccessful (app. 2). In the broader Diablo Range study area, we documented only one nesting attempt, that was also successful, by a mixed-age pair (in 2018).

During the study period we recorded a total of 812 detections of single non-territorial, subadult Golden Eagles (1-4 years old) at focal survey sites. Non-territorial subadults were observed throughout much of the study area, but we regularly detected greater numbers of subadults at survey sites at the APWRA relative to survey sites in the surrounding landscape (fig. $3 A$ ). On average, we detected over four times as many non-territorial subadults at sites overlapping with the APWRA (mean $=2.27$ subadults per site per year) relative to sites surveyed in the broader Diablo Range (mean $=0.52$ subadults per site per year; fig. $3 B$ ).

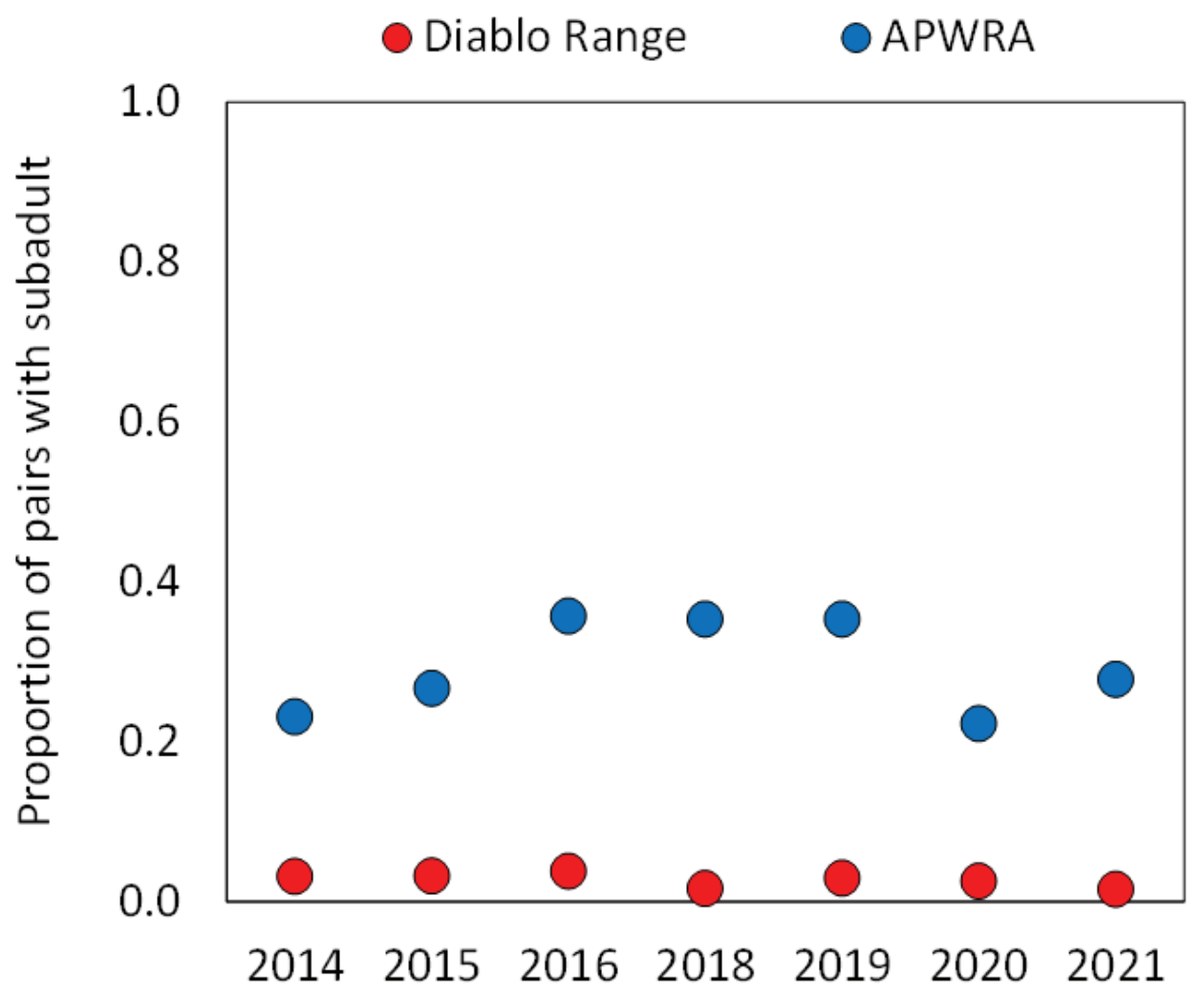

Year

Figure 2. Territorial pairs of Golden Eagles associated with the APWRA consistently included a higher proportion of subadult pair members relative to the surrounding Diablo Range study area during 2014-21 (surveys were not completed in 2017). Shown is the annual proportion of territorial pairs monitored in the APWRA versus the surrounding Diablo Range (not including APWRA) that included at least one pair member in subadult plumage (typically birds less than 5 years old). 


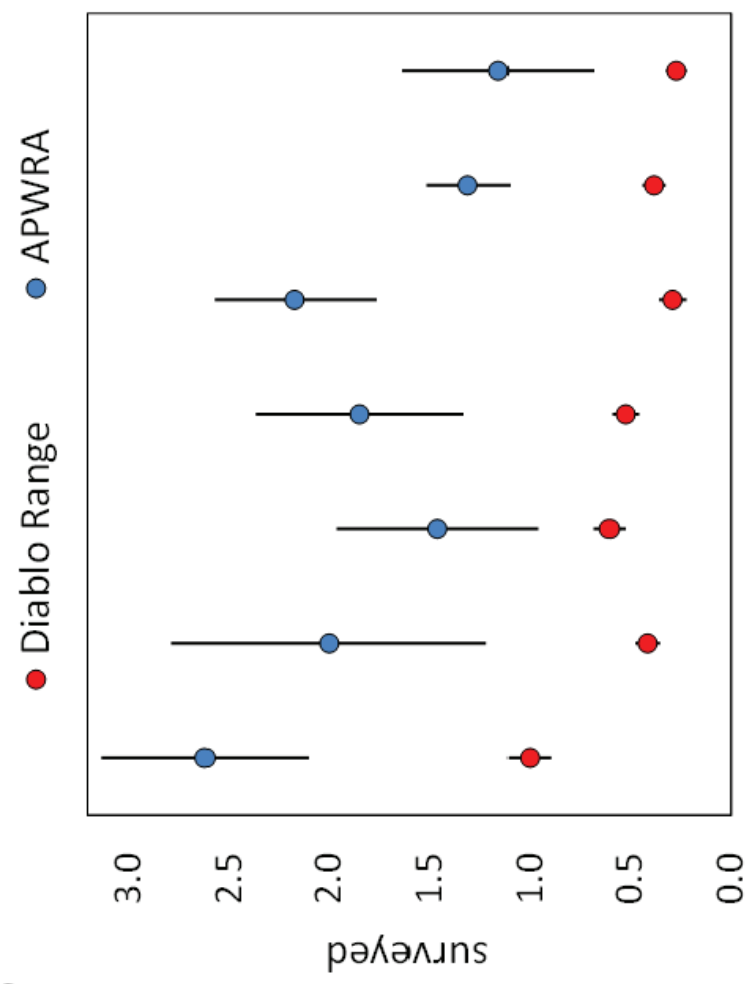

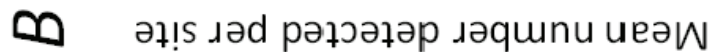
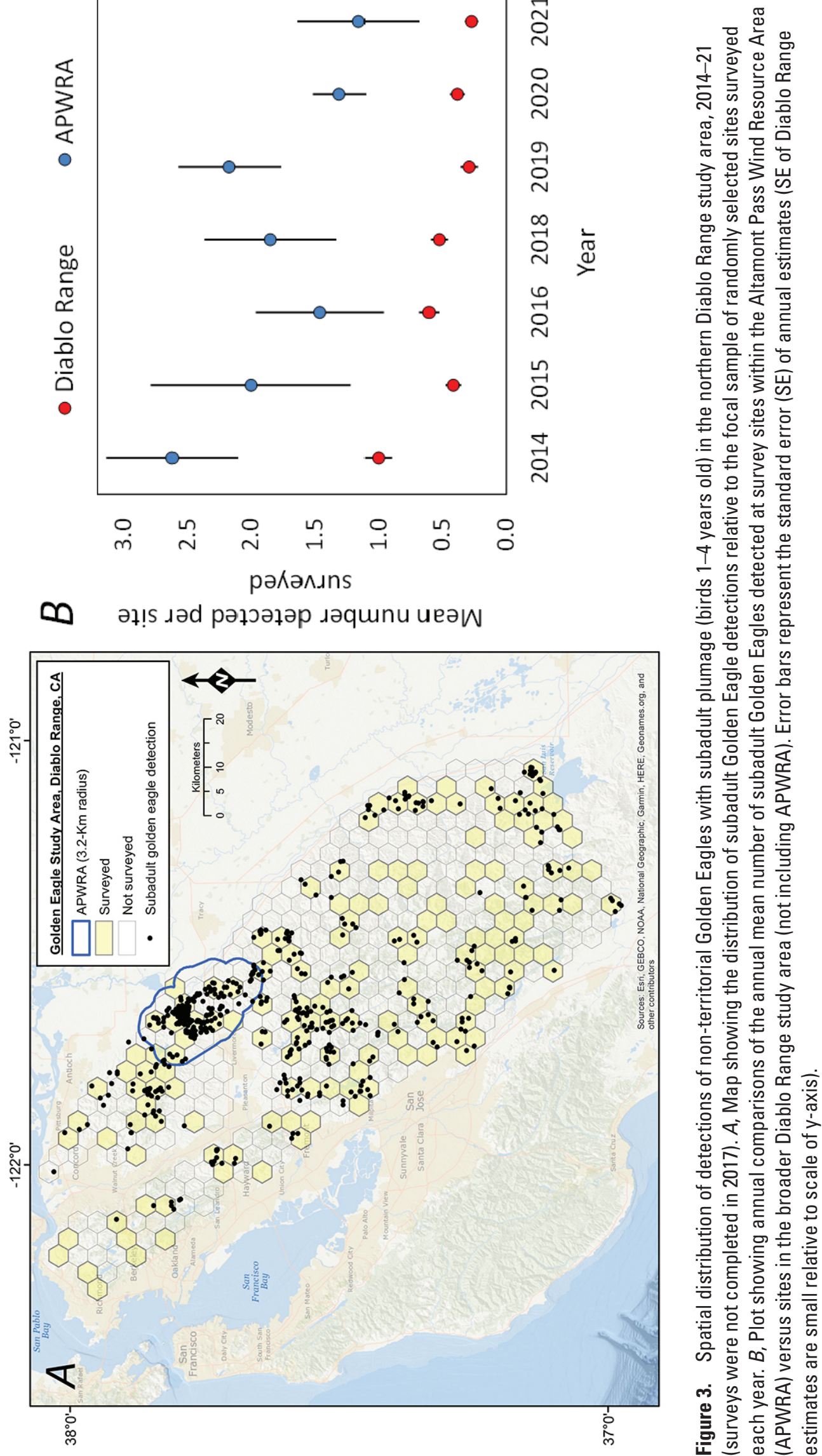


\section{Communal Roosting Behavior}

Golden Eagles have rarely been documented roosting together in groups (Katzner and others 2020). During our study we documented several communal roosting locations that appeared to be regularly used by all age classes of Golden Eagles (app. 2). For example, in 2015 we identified an individual Fremont cottonwood tree (Populus fremontii) in the APWRA where 6-10 subadult and adult eagles were observed perched together (Kolar and Wiens 2017). In more recent years, we found over 900 molted Golden Eagle feathers and at least one subadult Bald Eagle (Haliaeetus leucocephalus) tail feather below the same cottonwood roost tree and beneath adjacent California buckeye trees (Aesculus californica) and nearby rock piles. The large numbers of shed feathers suggested recent and repeated use of the communal roost area by multiple individuals, although we have only observed lone individuals in the tree during most surveys. In the spring of 2021, however, a pair of Golden Eagles was observed constructing a new (unused) nest structure in the cottonwood roost tree following a failed nearby nesting attempt in the Brushy Creek territory (app. 2). We have also regularly documented 2-3 subadult Golden Eagles perching together, and in a few instances, close to Bald Eagles in transmission towers along the eastern and western sides of the APWRA.

\section{Summary}

Since 2014 we identified the annual activity center locations for approximately 230 territorial pairs of Golden Eagles within the northern Diablo Range study area, including about 70 pairs we detected and monitored in areas outside the boundary of focal, randomly selected survey sites. Like previous years of the study, in 2021 we detected a relatively high density of territorial pairs at sites surveyed in the APWRA (mean $=0.77$ pairs detected per $13.85 \mathrm{~km}^{2}$ surveyed, or 1 pair per $18 \mathrm{~km}^{2}$ surveyed) that was comparable to sites surveyed in the surrounding Diablo Range (mean $=0.68$ pairs detected per $13.85 \mathrm{~km}^{2}$ surveyed, or approximately 1 pair per $20 \mathrm{~km}^{2}$ surveyed). Given the sampling design we used and the high probability of detecting pairs of eagles in our study (mean = 83 percent; Wiens and others, 2018, 2020), we believe these estimates are a reasonable approximation of average density of territorial pairs in the study area. However, these mean estimates do not account for a potentially large degree of spatial heterogeneity among survey sites in detection rates, landscape conditions, and site occupancy dynamics (for examples, Wiens and others $2015,2018,2020$ ). In 2019-21, the proportion of survey sites that were occupied by pairs of eagles $(0.58,0.55$, and 0.60 , respectively) was slightly lower than estimates from previous years of the study (0.61-0.66). Budget constraints and weather conditions in 2019 and 2020 limited our ability to survey approximately 25 of the sites surveyed in previous years, several of which had been occupied by territorial pairs, which may explain observed reductions in the number of pairs detected (and the proportion of sites surveyed with pairs) in 2019 and 2020. In 2021, we were able to resurvey sites not surveyed in the previous two years and subsequently detected pairs in many of the same historical territories. Forthcoming analyses will focus on how spatial variation in landscape conditions and other factors affect site-level occupancy, abundance, and reproductive output of Golden Eagles, while accounting for imperfect and variable detection rates of territorial pairs during surveys.

Between 2014 and 2021 we identified and mapped the annual activity centers for up to 21 pairs of Golden Eagles with territories overlapping with the APWRA (fig. 1.1). Evidence of nesting (that is, incubation or the presence of eggs/eggshells, nestlings, or fledglings) or nest construction/ refurbishment has been documented at least once at 18 of these territories during our study, including several territories monitored on lands within the Los Vaqueros Reservoir Watershed (app. 1, 2; Kolar and Wiens, 2017; H. T. Harvey and Associates, 2019, 2020). We also documented several pairs of eagles either nesting or constructing nest structures close $(<1.5 \mathrm{~km})$ to active wind turbines at the APWRA, or in areas targeted for future repowering or windfarm expansion. Based on historical records, we determined that some of the territorial pairs we detected at the APWRA and outside of the Los Vaqueros Reservoir Watershed had been documented prior to when our study was initiated in 2014 (see review by Kolar and Wiens 2017). For the most part, however, territorial pairs and their nesting locations were not systematically surveyed or monitored within the APWRA prior to our study. Consequently, it is unknown if many of the pairs we identified at the APWRA were present prior to 2014, or if these pairs are more recently established. Regardless, nesting pairs of Golden Eagles and their young are likely to face an increased risk of collisions from wind turbines that are located close to their nests, especially given the high frequency of use and territorial displays that can be expected near nesting locations. Flight displays associated with increased territorial behaviors near nests and young, for example, may distract individuals from aerial hazards such as rotating wind turbine blades. Our study underscores the importance of identifying the territorial status and annual nesting locations for Golden Eagles within the APWRA and other wind energy facilities, because this information can provide immediate options to reduce likelihood of wind turbine related fatalities (for example, the seasonal curtailment of wind turbine operations near pair activity centers, used nests, or regularly used roosting sites). 
An important observation from our study has been the distinct and consistent difference between the APWRA and surrounding landscapes in numbers of territorial and nonterritorial subadults detected during surveys. We caution that empirical data presented here do not account for imperfect and potentially low detection probabilities of subadult eagles, so estimates presented here may underestimate actual numbers present. Nonetheless, as in previous years of the study (Kolar and Wiens, 2017), from 2019 to 2021 we detected a high percentage (22-35 percent) of mixed-age (subadult/adult) territorial pairs within the APWRA, including one territory that was occupied by a pair of two subadults in 2018. This high percentage of subadult breeders in the APWRA contrasted sharply with observations in the broader Diablo Range study area, where only 3 percent of 119 territorial pairs monitored and aged included subadults, on average. The proportion of territorial pairs with subadults at the APWRA was also greater than reported in other studies that tracked the age distribution of territorial pairs of Golden Eagles (at most 17 percent; Steenhof and others, 1983; Sánchez-Zapata and others, 2000). In some cases, the incidence of breeding subadult pair members in eagle populations has been shown to indicate site-specific reductions in survival or displacement of territorial adults that were associated with human activities such as habitat loss from development or other land management activities, illegal shooting and poisoning, or disturbance and destruction of nests (Whitfield and others, 2004; Steenhof and others, 1983). Forthcoming analyses will investigate possible sources of spatial variation in use of survey sites by territorial and non-territorial Golden Eagles in our study area, and how such patterns may relate to population status and trend.

\section{Megafire-An Emergent Threat to Golden Eagles?}

Catalyzed by a changing climate, recent 'megafire' events in California during 2019-21 have hastened the need to quantify potential impacts of severe wildfire to biodiversity. In August and September of 2020, the Santa Clara Unit Lightning Complex Fire burned 159,294 hectares of the Diablo Range study area and affected at least 67 historical Golden Eagle territories identified in years before the fire (37 of which fell within our focal survey sites; fig. 4). In 2021 (first year post-fire), we detected 36 of 37 territorial pairs that we had previously detected and monitored within the fire perimeter during surveys completed in 2020. The single missing pair of eagles was at a site where access has been difficult, and detections of the pair have been intermittent since 2014 . The 2020 megafire event in the northern Diablo Range has provided an inimitable opportunity to use a natural BeforeAfter Control-Impact experimental design to investigate the population response of Golden Eagles to mixed-severity wildfire. With additional years of data, this design could address questions about: (1) how mixed-severity wildfire may impact site-occupancy and reproduction in a tree-nesting population of Golden Eagles, and (2) how wildfire impacts may interact with existing threats to affect population status and habitats used by Golden Eagles. 


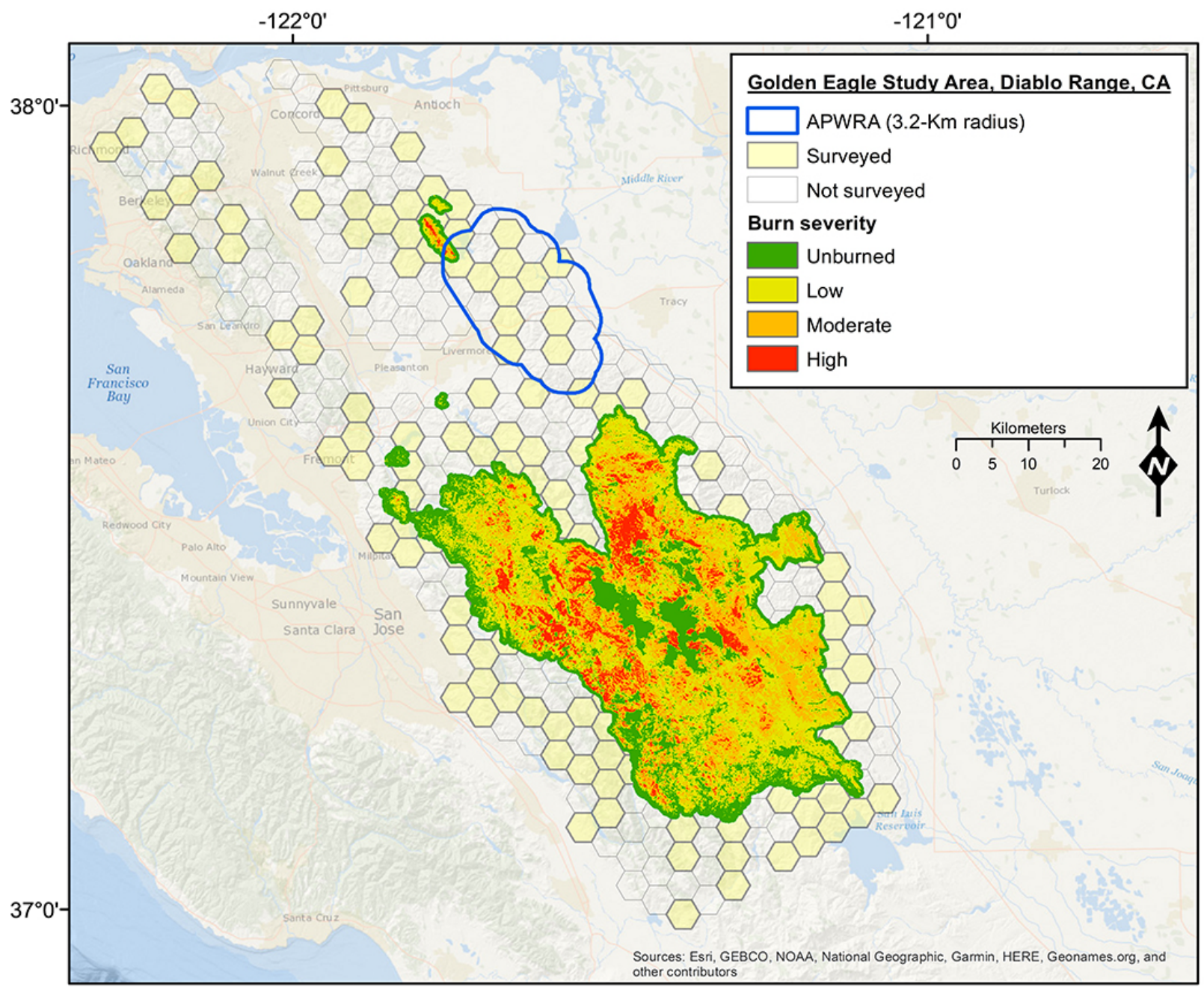

Figure 4. Location of the 2020 Santa Clara Unit Lightning Complex Fire in relation to the distribution of sites (highlighted hexagons) surveyed for Golden Eagles annually during 2014-21 (surveys were not completed in 2017). [APWRA, Altamont Pass Wind Resource Area; burn severity data from U.S. Geological Survey, 2020].

\section{Acknowledgments}

We thank Terry Hunt, Grainger Hunt, Craig Himmelwright, Step Wilson, Ben Dudek, Misty Cain, Andy Bradshaw, Stephanie Klein, Doug Bell, Harvey Wilson, Joe DiDonato, Christine Cariño, Caleb Murphy, Mandy Murphy, Colleen Lenihan, Eric Jepsen, Jeff and Cooper Smith, Danika Tsao, Shawn Smallwood, Brad Schafer, Caitlyn Bishop, Ode Bernstein, and members of the East Bay Regional Parks District Golden Eagle Monitoring Team volunteer group for their field assistance and for providing information on Golden Eagles. We thank Renee Culver at NextEra Energy for coordinating access to APWRA and assisting with research logistics. Our work would not have been possible without support from the East Bay Regional Park District, California Department of Fish and Wildlife, California State Parks, San Francisco Public Utilities Commission, Santa Clara County Parks, Santa Clara Open Space Authority, East Bay Municipal Utility District, Contra Costa Water District, The Nature Conservancy, S-Power, Salka Energy, Brookfield Renewable, and many other landowners that provided us with permission to access their lands to survey eagles. Comments and suggestions from two reviewers improved the overall quality of this report. Any use of trade, product, or firm names is for descriptive purposes only and does not imply endorsement by the U.S. Government. 


\section{References Cited}

Driscoll, D., 2010, Protocol for Golden Eagle occupancy, reproduction, and prey population assessment-Apache Junction: Arizona, American Eagle Research Institute, 55 p.

Fratanduono, M.L., 2014, Final report Bald and Golden Eagle territory surveys for the Lawrence Livermore National Laboratory: Livermore, California, Lawrence Livermore National Laboratory, No. LLNL-SR-664876, 11 p.

Harvey, H.T., and Associates, 2019, Los Vaqueros Reservoir Project annual Golden Eagle monitoring report 2019: Los Gatos, California, Contra Costa Water District Project 3912-03/04, prepared by H. T. Harvey and Associates, 32 p.

Harvey, H.T., and Associates, 2020, Los Vaqueros Reservoir Project annual Golden Eagle monitoring report 2020: Los Gatos, California, Contra Costa Water District Project 3912-04/05, prepared by H. T. Harvey and Associates, 33 p.

Hunt, W.G., Wiens, J.D., Law, P.R., Fuller, M.R., Hunt, T.L., Driscoll, D.E., and Jackman, R.E., 2017, Quantifying the demographic cost of human-related mortality to a raptor population: PLoS One, v. 12, no. 2, 22 p., accessed February 25, 2017, at https://doi.org/10.1371/ journal.pone.0172232.

Katzner, T.E., Kochert, M.N., Steenhof, K., McIntyre, C.L., Craig, E.H., and Miller, T.A., 2020, Golden Eagle (Aquila chrysaetos), version 2.0, in Rodewald, G., and Keeney, B.K., eds., Birds of the World v. P: Ithaca, New York, Cornell Lab of Ornithology, https://doi.org/10.2173/ bow.goleag.02.

Kolar, P.S., and Wiens, J.D., 2017, Distribution, nesting activities, and age-class of territorial pairs of Golden Eagles at the Altamont Pass Wind Resource Area, California, 2014-16: U.S. Geological Survey Open-File Report 2017-1035, 18 p., accessed March 22, 2017, at https://doi.org/10.3133/ ofr20171035.

MacKenzie, D.I., Nichols, J.D., Royle, J.A., Pollock, K.H., Bailey, L., and Hines, J.E., 2017, Occupancy estimation and modeling-Inferring patterns and dynamics of species occurrence: London, United Kingdom, Elsevier, 324 p.
Mete, A., Stephenson, N., Rogers, K., Hawkins, M.G., Sadar, M., Guzman, D.S.M., Bell, D.A., Smallwood, K.S., Wells, A., Shipman, J., and Foley, J., 2014, Knemidocoptic mange in wild golden eagles, California, USA: Emerging Infectious Diseases, v. 20, no. 10, p. 1716-1718, accessed November, 2021, at https://doi.org/10.3201\%2Feid2 010.140504 .

Orloff, S., and Flannery, A., 1992, Wind turbine effects on avian activity, habitat use and mortality in Altamont Pass and Solano County Wind Resource Areas, 1989-91: Tiburon, California, California Energy Commission, prepared by BioAnalysis Systems Inc., 199 p.

Pagel, J.E., Whittington, D.M., and Allen, G.T., 2010, Interim Golden Eagle inventory and monitoring protocols and other recommendations: Carlsbad, California, US Fish and Wildlife Service, Division of Migratory Bird Management, $31 \mathrm{p}$.

Sánchez-Zapata, J.A., Calvo, J.F., Carrete, M., and Martínez, J.E., 2000, Age and breeding success of a Golden Eagle Aquila chrysaetos population in southeastern Spain: Bird Study, v. 47, no. 2, p. 235-237.

Smallwood, K.S., and Thelander, C., 2008, Bird mortality in the Altamont Pass wind resource area, California: The Journal of Wildlife Management, v. 72, no. 1, p. 215-223, accessed December, 2013, at https://doi.org/10.2193/ 2007-032.

Steenhof, K., Kochert, M.N., and Doremus, J.H., 1983, Nesting of subadult Golden Eagles in Southwestern Idaho: The Auk, v. 100, no. 3, p. 743-747, accessed January, 2013, at https://doi.org/10.1093/auk/100.3.743.

U.S. Fish and Wildlife Service, 2013, Eagle conservation plan guidance, module 1-Land-based wind energy, (ver. 2): Falls Church, Virginia, U.S. Fish and Wildlife Service, Division of Migratory Bird Management, 103 p., accessed December 30, 2016 at http://www.fws.gov/migratorybirds/ PDFs/Eagle\%20Conservation\%20Plan\%20GuidanceModule\%201.pdf. 
U.S. Geological Survey, 2020, Burn area reflectance classification (BARC) data bundle for the SCU Lightning Complex fire occurring on the Santa Clara Unit-2020: Sioux Falls, South Dakota, U.S. Geological Survey Earth Resources Observation and Science Center, BAER Imagery Support Program, accessed January 15, 2021, at https://fsapps .nwcg.gov/baer/.

Whitfield, D.P., Fielding, A.H., McLeod, D.R., and Haworth, P.F., 2004, The effects of persecution on age of breeding and territory occupation in Golden Eagles in Scotland: Biological Conservation, v. 118, no. 2, p. 249-259, accessed March, 2015, at https://doi.org/10.1016/ j.biocon.2003.09.003.
Wiens, J.D., Kolar, P.S., Fuller, M.R., Hunt, W.G., and Hunt, T.L., 2015, Estimation of occupancy, breeding success, and predicted abundance of Golden Eagles (Aquila chrysaetos) in the Diablo Range, California, 2014: U.S. Geological Survey Open-File Report 2015-1039, 23 p., accessed June, 2015, at https://doi.org/10.3133/ofr20151039.

Wiens, J.D., Kolar, P.S., Hunt, W.G., Hunt, T., Fuller, M.R., and Bell, D.A., 2018, Spatial patterns in occupancy and reproduction of Golden Eagles during drought_-Prospects for conservation in changing environments: The Condor, v. 120, no. 1, p. 106-124, accessed January 4, 2018, at https://doi.org/10.1650/CONDOR-17-96.1.

Wiens, J.D., Kolar, P.S., and Bell, D.A., 2020, Distribution and abundance of Golden Eagles in East Contra Costa County, California: U.S. Geological Survey Open-File Report 2020-1107, 13 p. 


\section{Appendix 1. Map of Survey Sites and Activity Centers Used by Territorial Pairs of Golden Eagles in the Altamont Pass Wind Resource Area, 2019-21}

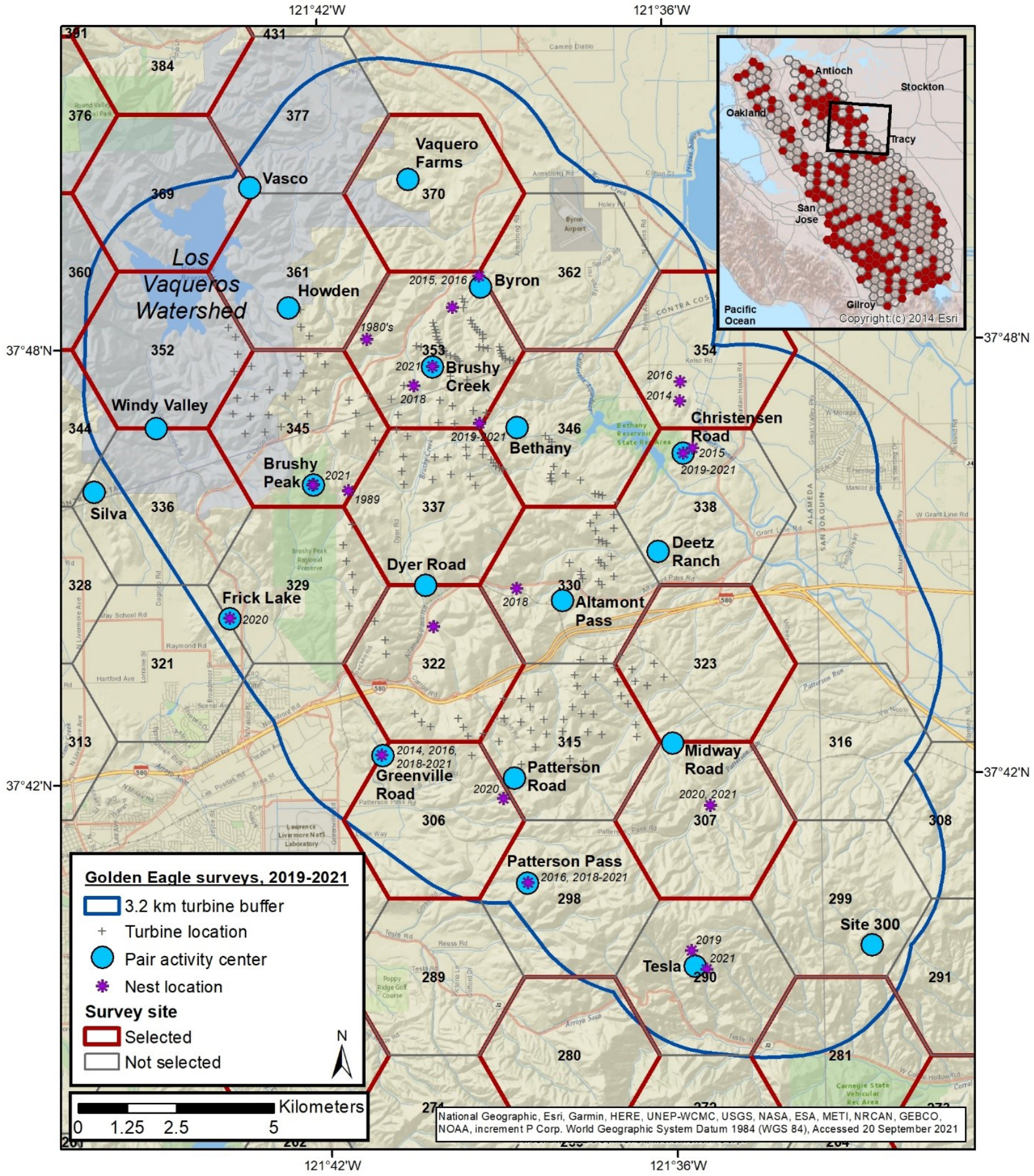

Figure 1.1. Distribution of activity center locations for territorial pairs of Golden Eagles detected within 3.2 kilometers of historical and current wind turbines at the Altamont Pass Wind Resource Area, California, 2019-21. Nests shown with evidence of use by Golden Eagles (observations of nest-construction, incubating adults, eggs laid, or young present) and year of confirmed use. Nest locations monitored within the Los Vaqueros Watershed are not shown. 


\section{Appendix 2. Territory-Specific Observations of Territorial Pairs of Golden Eagles Located near the Altamont Pass Wind Resource Area, 2019-21}

\section{Tesla (hexagon 290)}

In previous years Golden Eagles associated with the Tesla territory have primarily been detected outside of our survey area in site 290 , but also partially within adjacent sites to the north, northwest, and northeast. In 2019, we obtained few observations of the adult territorial pair but did confirm incubation in a large valley oak tree (Quercus lobata). This pair successfully fledged one young that was radio-marked as part of a separate study, but it was found dead shortly afterwards (Doug Bell, East Bay Regional Park District, unpub. data, 2019). In 2020 we observed an adult male and older subadult female with white at the base of some outer tail feathers perching and undulating in the usual pair activity center at the start of the season. During subsequent visits to the site, we observed the lone adult male defending the territory and found the 2019 nest had some new nesting material, but no sign of use. Road conditions prevented us from searching for nesting elsewhere until the end of the season when we found the adult male and subadult female again perched near a new nest that had been blown out of a large gray pine tree (Pinus sabiniana) and scattered on the ground. We were unable to determine if eggs had been laid in this new nest during 2020. In 2021 we determined the territorial pair consisted of two adults and they successfully fledged one young from a new nest that had been rebuilt in the same tree that was used during the previous year.

\section{Site 300 (hexagon 299)}

In 2014 an adult pair of Golden Eagles was observed in the Lawrence Livermore Laboratory's Site 300, within 2-miles of the southeastern portion of the APWRA near the boundary of sites 291 and 299 (Fratanduono, 2014). There are few previous records of nest locations within this territory, aside from a single record of a nest on a distribution line pole in this area from 1996 (Fratanduono, 2014) and an old, unused nest on a rock outcrop further east that we found had collapsed and destroyed the nest ledge by 2018. In 2015, 2016, and 2018 a pair that was thought to be associated with the same territory was briefly observed farther to the east each year. However, in 2020 we observed a mixed-age pair perching together in this further area and saw an adult pair of eagles perching and undulating together in the historical Site 300 territory within the APWRA buffer at the same time. We subsequently observed this pair in Site 300 on numerous occasions with simultaneous observations of all other known territorial pairs nearby (Tesla, Patterson Pass, Midway Road). We were unable to access this area of activity to determine nesting status. In 2021 we observed a lone adult eagle perching and hunting in this same area but saw no signs of territorial behavior or a mate.

\section{Patterson Pass (hexagon 298)}

The Patterson Pass pair consisted of two adults in 2019 and 2020 and was primarily observed outside of our focal survey area in site 298. In both years we confirmed incubation by the pair in two different nests in the same valley oak tree used during 2016 and 2018. In 2019 the nesting attempt failed during the early incubation or nestling stages for unknown reasons. In 2020 the pair fledged one young that was radiomarked as part of a separate study (Doug Bell, East Bay Regional Park District, unpub. data, 2020). The adult male was also observed to have potential damage to the outer portion of one wing that seemed to cause limitations in flight during that time. In 2021 we observed both adults and confirmed at least one fledgling from the historical nest tree, but saw no signs of wing damage or flight problems by the male that was suspected in the previous year.

\section{Greenville Road (hexagon 306)}

As in previous years, we observed the adult pair associated with this territory roughly between Greenville Road, Patterson Pass Road, and Interstate 580. The only known nest associated with this territory was in a eucalyptus tree in the northwestern corner of 306. The pair of Golden Eagles occupying this territory used this same nest in nearly every year of the study, successfully fledging 2 young in 2019 , at least one young in 2020, and two young again in 2021.

\section{Patterson Road (hexagon 315)}

In 2018 we confirmed occupancy of the Patterson Road territory (and others nearby) with simultaneous observations of adjacent territorial individuals. During the 2019 season we observed a pair of Golden Eagles that appeared to consist of and adult and older subadult with white in some outer tail feathers perching together during limited observations outside of our focal survey area in the center and southwestern corner of site 315 . In 2020 we were unable to confirm occupancy of the territory until the end of the season when we detected an adult pair perching with a fledgling near the southwestern 
portion of site 315 . We later located a nest nearby with a flattened bowl lining indicating use and perch locations with adult and fledgling feathers in the few trees and rock outcrops within $0.25-0.5$ miles away. In 2016, we also observed an adult Golden Eagle flying with nesting material in this same area, indicating a nest may have at least been under construction at that time, but were not able to determine the exact nest location. During the 2021 season we observed the pair perched and hunting together but did not see any sign of nesting activity or fledglings.

\section{Midway Road (hexagon 307/323)}

The Midway Road territory consisted of an adult and subadult in 2019. In 2019 we observed the pair perching in transmission towers in their historical activity center in survey site 323, then perched in transmission towers, a meteorological evaluation tower, and defunct turbines near the intersection of sites 307, 315, and 323 later in the season. In 2020 we detected the pair together in these same areas early in the season and confirmed the male was an adult and the female was an older subadult with white in some outer tail feathers. In early to mid-March this female was observed in incubation posture on a new nest in a Fremont cottonwood tree near the center of site 307 . In early May we confirmed the pair was brooding two 1-2-week-old nestlings. In late May we observed at least one young approximately 4 weeks old. The nestling was not observed on subsequent visits and we later confirmed nest failure following several days of extreme temperatures and a grass fire that burned within 50 meters (m) of the nest. During 2021 the adult pair successfully fledged two young from the same nest, both of which were radio-marked as part of a separate study (Doug Bell, East Bay Regional Park District, unpub. data, 2021).

\section{Frick Lake (hexagon 329)}

In 2020 we confirmed a new pair of Golden Eagles overlapping with site 329 . The adult male was initially detected capturing a ground squirrel while we were monitoring a golden eagle pair associated with the Dyer Road territory on a ridgetop in the eastern portion 329 , within the construction site for a wind energy project that became operational a year later in 2021. The male then flew 2 miles west toward Vasco Road and delivered the prey to an adult female incubating on a nest in a eucalyptus tree along a driveway near the outskirts of Livermore. Later, we confirmed two fledged young from this nest. It is unknown how long this territory has been occupied. We documented the same nest in previous years, but found no signs of use in it at the time. In 2021 the nest was no longer present in the eucalyptus tree grove and we saw no sign of nesting elsewhere. The female also appeared to be a subadult based on plumage characteristics and the center of activity shifted slightly to the north of the historical nest, though the male was still observed hunting in the western portion of the APWRA.

\section{Altamont Pass (hexagon 330)}

In 2019 the Altamont Pass pair consisted of an adult and subadult that were observed undulating and perching together near the intersection of site 322 and 330, primarily outside of our focal survey area. We confirmed the only known nest for this territory from 2018, located on top of a rock in an old road-cut, was not used but could not check all other nesting substrates due to constraints in accessing some properties. However, we did observe a fledgling perching and flying low in the activity center late in the breeding season. Given the nearest known successful pairs of nesting Golden Eagles were 5-6 kilometers away, this fledgling was assumed to be associated with the Altamont Pass territory. In 2020 we observed an adult pair in the Altamont Pass territory throughout site 330. We documented a fledgling flying and perching with the pair in the central portion of 330 on multiple days in late June, but again were unable to determine the nest location due to limited access to surrounding lands. In 2021 we confirmed occupancy of the territory by an adult pair but did not see any signs of nesting or fledglings. During 2020 and 2021 we also observed 3 subadult or juvenile Golden Eagles flying and perching together in a small eucalyptus grove, located approximately one-half mile south from the 2018 Altamont Pass nest near the boundary of sites 322 and 330, at any given time, which may indicate another communal roost area.

\section{Dyer Road (hexagon 337)}

A pair of Golden Eagles consisting of an adult male and an older subadult female with white at the base of some outer tail feathers was observed perching, hunting, and undulating together near the historical activity center for the Dyer Road territory near the intersection of sites 322,329 , and 337 during 2019 and 2020. We found no sign of nest structures in the area but were unable to check the large numbers of eucalyptus trees near located behind private residences along Dyer Road where the pair has been observed in previous years. In 2021 the territorial pair was still using this same area, but most of the activity had shifted back to the center of site 322 where it was located in previous years. The pair again consisted of mixedage eagles, but on multiple occasions we observed the female to be a full adult and the male to be a younger subadult with full white at the base of the tail. We saw no signs of nesting activity, but both individuals were observed flying with sticks and dropping them on the ground in a loose pile on top of a hill near their primary perch. 


\section{Deetz Ranch/Jess Ranch (hexagon 338)}

The Deetz Ranch pair consisted of an adult and subadult in 2019 and 2020. They were observed perching in transmission towers together and hunting in the southern portion of site 338 and northeastern portion of 330 outside of our focal survey area, but also in the southeast corner of focal site 346 . In 2020 the subadult appeared to be a female and was observed with a backpack radio-transmitter that is either non-functional or associated with an unknown study. We found no evidence of nesting activity, but the pair was frequently perched in the southern half of site 338 near a small wooden utility pole with a nest under construction on top of a defunct transformer. In 2021 we observed an adult pair of eagles perching together in the same area, one of which appeared to have a backpack transmitter. We saw no signs of nesting activity or fledglings in the territory but were unable to survey the area sufficiently later in the season due to access issues.

\section{Christiansen Road (hexagon 338)}

As in previous years, we observed a pair of Golden Eagles associated with the Christiansen Road territory primarily on the east side of Bethany Reservoir overlapping with survey sites 338, 346, and 354. In 2019, 2020, and 2021 we confirmed incubation by the adult pair in a new nest located in a small non-native river she-oak tree (Casuarina equisetifolia) overlapping with the northern portion of site 338. The Golden Eagle pair successfully fledged two young in each of these three years.

\section{Brushy Peak (hexagon 345)}

During each year from 2019 to 21, we observed an adult pair of Golden Eagles flying with nesting material into a group of small coast live oak trees (Quercus agrifolia) on the northeast side of Brushy Peak where we previously found a nest under construction in 2018. We detected the pair perching and hunting together elsewhere in southeast 345 and in the northwest portion of site 337. At the end of the 2020, we hiked to the area of activity and found a second previously unknown nest under construction $10 \mathrm{~m}$ away from the one started previously. We found no evidence that eggs were laid in either nest or other signs of reproduction during the season (in other words, nesting behaviors or fledglings). In 2021 we confirmed incubation in the first nest started in 2018 and, later in early May, observed a single nestling estimated to be 3.5 weeks of age based on plumage. By late May we found little left of the nestling aside from scattered feathers in and under the nest tree. We found no clear sign as to the cause of nest failure and both adults were still observed nearby in the territory. We also determined at least one adult had 1 to 2 retained subadult tail feathers, confirmed from observations of plumage during our surveys and by locating these feathers shed under the nest at the end of the season, indicating replacement of a pair member with a younger adult. Since 2014, we have also identified the vicinity of Brushy Peak (site 345) as a communal roosting area. From 2014 to 2016 we observed numerous Golden Eagles and occasionally Bald Eagles perching together or in separate scattered oak and California buckeye trees near the top of the peak. After the territorial pair began constructing nests in this area, the communal roosting activity by other eagles appeared to have shifted to a lower peak one-quarter to one-half mile southwest.

\section{Bethany (hexagon 346)}

In 2019 the Bethany pair consisted of two adults that successfully fledged one young from a new nest in a eucalyptus tree near the intersection of survey sites 337,346 , and 353. As in previous years, the annual area of activity was primarily on the west side of Bethany Reservoir in site 346 where they were frequently detected hunting and undulating when not near the nest. The adult female was observed, during our surveys and by other biologists/wind energy personnel, to have feather loss on the head consistent with potential mange caused by Micnemidocoptes mites (Mete and others, 2014) throughout the spring and summer. There was no sign of feather loss in the mate or fledgling. In 2020 the pair consisted of two adults again and neither showed signs of mange. The pair successfully fledged two young from the same nest, but both died shortly afterwards. One fledgling reportedly flew into the side of a road grader and was taken to Lindsay Wildlife Rehabilitation Center where it was euthanized due to its injuries (Renee Culver, NextEra Energy, written commun., 2020). The second fledgling was found during our surveys on the ground $100 \mathrm{~m}$ from the nest tree with no obvious signs indicating the cause of death. In 2021 the adult pair fledged two young from the same nest, but one was found dead on the ground nearby a couple weeks later by personnel associated with the wind energy project, again with no obvious sign of as to the cause (Renee Culver, NextEra Energy, written commun., 2021).

\section{Silva (hexagon 336), Windy Valley (hexagon 352), Howden (hexagon 361), Vasco (hexagon 377), and Camino Diablo (hexagon 369)}

Information on Golden Eagle territories on the Los Vaqueros Watershed was collected as part of long-term monitoring program (H. T. Harvey and Associates 2019, 2020) and shared with our study. The Silva territory was determined to 
be occupied in 2019, but the pair was observed outside of the APWRA buffer and was not detected in subsequent years.

The Windy Valley pair used two different historical nests near the boundary of site 336 and 352 from 2019 to 21 . The Vasco pair used two new nests along the boundary of survey site 369 and 377 during 2019 and 2020. The Camino Diablo pair used two historical nests overlapping with focal site 369 , but outside of the 3.2 kilometers APWRA buffer during 2019 and 2020. All three pairs were determined to have failed during the incubation or nestling stage for unknown reasons in 2019 (H. T. Harvey and Associates 2019). In 2020 the Windy Valley and Camino Diablo pairs each fledged one young and the Vasco pair fledged two young (H. T. Harvey and Associates 2020). During 2021 the Windy Valley pair failed in their nesting attempt. The Camino Diablo and Vasco territories both experienced turnover of female pair members with adults being replaced by subadults and no signs of nesting during 2021 (Colleen Lenihan, H. T. Harvey and Associates, written commun., 2021). The Golden Eagle pair associated with the Howden territory was observed refurbishing their only known historical nest every year with no sign that eggs were ever laid. The female at this territory continued to appear unable to breed after becoming permanently disabled from a suspected collision with a powerline or wind turbine in 2012-13 $(\mathrm{H}$. T. Harvey and Associates 2020). See reports from the Los Vaqueros Watershed Golden Eagle Monitoring Program for more details.

\section{Brushy Creek (hexagon 353)}

The pair of Golden Eagles associated with the Brushy Creek territory consisted of two adults that primarily overlapped with the southern half of site 353 and northwest portion of 337. Between January and March of 2019-21, we observed the pair bringing nesting material into the same eucalyptus tree that had been refurbished in 2015, 2016, and 2018. Visibility of the nest was poor, making it difficult to determine if the pair laid eggs or could have failed early due to potential disturbance from concurrent fence and pipeline work conducted 100-300 m away from the tree in 2019 and 2020. In 2021 we confirmed the pair began nesting in early March, just before a large windstorm. Less than one week later we determined the nest had failed and found a broken egg under the nest with some nesting material blown out. Later in the season during at least April and May, the pair appeared to be constructing a new nest in the communal roost tree approximately 1-mile to the south.

\section{Byron (hexagon 353)}

During our first survey in 2019, we observed an adult pair perched together in their historical activity center in the northeast portion of site 353. By the next survey in March, we found the adult male copulating with a subadult female near the same location with no sign of the previous adult female mate. Over two days during the third survey in mid-May we observed the adult pair again perching in a eucalyptus tree where an alternate nest was previously located. The adult female appeared to show signs of mange, continuously scratching at back of head where feather loss was becoming more visible. In 2020 neither adult showed signs of mange or feather loss. They were observed rebuilding the alternate nest again, but we found no signs of use and it had blown out of the tree by the end of the season. In 2021 the adult pair was observed on multiple occasions in the same area and began rebuilding the alternate nest, but it had fallen out of the tree by the end of the season for a third year in a row. We found no other signs of nesting activity by this pair.

\section{Vaquero Farms (hexagon 370)}

In 2018 we used multiple surveyors to simultaneously observe the Vaquero Farms Golden Eagle territory and others nearby (in other words, Vasco, Brushy Creek, Byron, and Howden) to confirm it was different after some confusion during 2014-2016 (Kolar and Wiens 2017). During the first survey in 2019, we observed an adult pair just once undulating and perching in the northwest portion of site 370 , despite numerous attempts to find them during subsequent survey occasions. We were unable to determine if the pair was missed during subsequent surveys or if we mistakenly identified the Vasco pair that overlaps with this area as well. In 2020 one adult was seen hunting in the northwestern portion of 370 then flying with prey toward the Vasco nest area. We observed lone eagles elsewhere in the Vaquero Farms territory but saw no signs of territorial behavior. During February 2021 we observed an adult pair of Golden Eagles perching and hunting together in the historical Vaquero Farms area of activity, two days after a subadult female was confirmed to have replaced the adult female at the Vasco territory (Colleen Lenihan, H. T. Harvey and Associates, written commun., 2021). We observed at least one eagle perched near the historical Byron nest at the same time as the adult pair observation at Vaquero Farms and none of the eagles show signs of flight or wing impairment typical of the Howden female. In late April we observed a pair of Golden Eagles perching and hunting together in the same area at Vaquero Farms, but this time saw one of them was a subadult with full white at the base of all tail feathers. We found no evidence of nesting at the time and only observed a lone adult in the area during subsequent surveys. 

Publishing support provided by the U.S. Geological Survey Science Publishing Network, Tacoma Publishing Service Center

For more information concerning the research in this report, contact the Director, Forest and Rangeland Ecosystem Science Center U.S. Geological Survey

777 NW 9th St., Suite 400

Corvallis, Oregon 97330

https:///www.usgs.gov/centers/fresc/ 


\section{$\frac{\mathbb{2}}{\mathrm{C}}$}

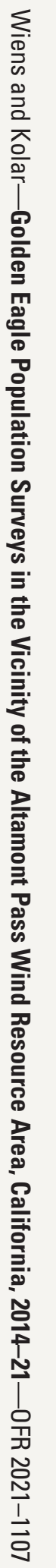

